\title{
Bacterial Endosymbiosis in Paramecium aurelia: Bacteriophage-like Inclusions in a Kappa Symbiont
}

\author{
By I. STEVENSON* \\ Department of Developmental Biology, Research School of Biological Sciences, \\ The Australian National University, Post Office Box 475, Canberra, \\ A.C.T. Australia 2601 \\ (Accepted for publication 5 January 1972)
}

SUMMARY

The bacterial endosymbiont kappa of stock A35 of Paramecium aurelia (syngen 2) carries virus-like inclusions after it has developed a refractile or $\mathrm{R}$ body which is necessary for kappa to exert the killing effect.

In exponentially growing Paramecium, the proportion of symbionts bearing $\mathrm{R}$ bodies and virus-like inclusions is very low. On starvation, $R$ bodies and virus-like inclusions reappear, and the proportion builds up to between one-quarter and onehalf of the total number of symbionts in a cell. Thus the development of $R$ bodies, virus-like inclusions and killing action is influenced by the environment of the host Paramecium cell.

\section{INTRODUCTION}

Bacterial endosymbiosis is common in Paramecium aurelia, and a number of differing types of endosymbiont has been described, each type being denotedby a Greek letter (review by Beale, Jurand \& Preer, 1969; see also Stevenson, 1970).

The most extensively studied symbionts are those of the kappa type, one of which was the first known symbiont of Paramecium aurelia (Sonneborn, 1943). Several distinct varieties of kappa have now been recognized (Beale et al. 1969). All are distinguished by the possession, at some time, and in some of the symbionts, of membranous structures known as refractile (R) bodies, with which the well-known killing effect is associated. Two previously described varieties of kappa symbionts have a small number of virus-like inclusions associated with the R body (Preer \& Preer, 1967; Preer \& Jurand, I968). A third example of such a symbiont was described briefly by Stevenson (1970). This paper will describe some features of the relationship between the host paramecium, the bacterial endosymbiont and its bacteriophagelike inclusions, in such a stock of $P$. aurelia.

\section{METHODS}

The symbionts of stock A 35 of Paramecium aurelia have been described earlier (Stevenson, 1970) but a detailed description of the stock itself was not given. It was collected from the Murrumbidgee River at Uriarra Crossing, Australian Capital Territory, in November, 1969. Further visits to the collection site have failed to repeat the collection. On the basis of its morphology stock A35 probably belongs to syngen 2 of $P$. aurelia, but this tentative identification has not been confirmed as mating reactivity has not been obtained. This is a frequent difficulty with syngen 2 (Sonneborn, I950).

\footnotetext{
* Present address: Electron Microscope Unit, School of Life Sciences, N.S.W. Institute of Technology,
} Thomas Street, Broadway, N.S.W., Australia 2007. 

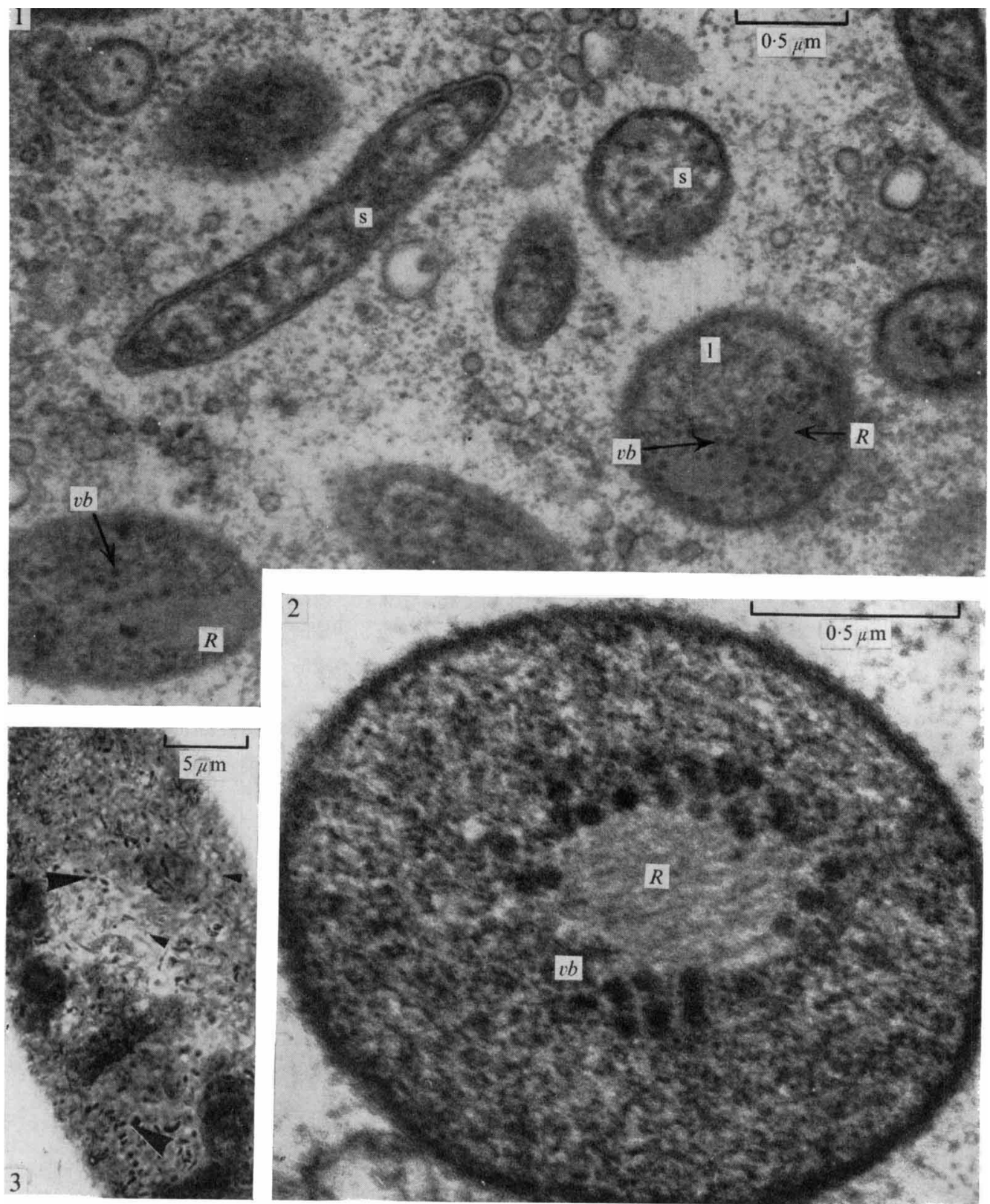

Fig. I. Stock A35. Virus-bearing (l) and non-virus-bearing (s) forms of the kappa endosymbiont. An $R$ body is evident ( $R$ ).

Fig. 2. Virus-like inclusions $(v b)$ clustered around the $\mathrm{R}$ body $(R)$ of a large form of the symbiont, seen in transverse section.

Fig. 3. Stock A35. Large and small forms of the kappa endosymbiont as seen under dark phasecontrast. Small arrows indicate small forms, large arrows large forms. Whole mount, stained by $\mathrm{OsO}_{4}$-lacto-orcein. 
Table I. Association of $R$ bodies and virus-like inclusions viewed in the electron microscope in sections of kappa endosymbionts of stock A35 after starvation

Total number of sections counted: I 44 (43 large, Ior small). Percentage of large forms $43 / 144=29 \cdot 9 \%$.

\begin{tabular}{|c|c|c|c|}
\hline \multirow[b]{2}{*}{ Kappa form } & \multirow[b]{2}{*}{ Range } & \multicolumn{2}{|c|}{$\begin{array}{l}\text { Numbers of virus-like inclusions } \\
\text { observed in each section }\end{array}$} \\
\hline & & $\begin{array}{l}\text { No. of sections } \\
\text { of symbionts }\end{array}$ & Mean \\
\hline Large ( $\mathrm{R}$ body present) & $\begin{array}{c}\text { O } \\
\text { I to } 10 \\
\text { II to } 20 \\
\text { 2I to } 30 \\
\text { 3I to } 40 \\
\text { 4I to } 50 \\
\text { 5I to } 60 \\
6 \text { I to } 70 \\
>70\end{array}$ & $\left.\begin{array}{r}0 \\
8 \\
10 \\
12 \\
9 \\
2 \\
1 \\
1 \\
0\end{array}\right\}$ & $24 \cdot 7$ \\
\hline Small (R body absent) & $\begin{array}{c}0 \\
\text { I to IO } \\
\text { II to } 20 \\
>20\end{array}$ & $\left.\begin{array}{r}81 \\
19 \\
1 \\
0\end{array}\right\}$ & 0.74 \\
\hline
\end{tabular}

Culture methods and electron microscopy were described by Stevenson (I970). Cell numbers were counted by removing cells one by one from a sample of culture; symbiont numbers were counted by taking representative fields of random cells prepared by the $\mathrm{OsO}_{4}$-lactoorcein method (Beale \& Jurand, 1966) and counting symbionts with the aid of a squared grid in the ocular. Symbionts bearing $\mathrm{R}$ bodies ('large') may be distinguished from those not having $\mathrm{R}$ bodies ('small') by their different size (particularly breadth) and the fact that large forms stain more intensely.

\section{RESULTS}

The relationship of $R$ bodies and virus-like inclusions

In starved cells of stock A35 of Paramecium aurelia, the kappa endosymbionts fell into two classes: large ones with $\mathrm{R}$ bodies, and small ones without $\mathrm{R}$ bodies (Fig. I). The $\mathrm{R}$ body of this kappa symbiont was cylindrical, about I $\mu \mathrm{m}$ long and $0 \cdot 2 \mu \mathrm{m}$ across, appearing as a stack of flat membranes, parallel to its long axis. Large forms had virus-like inclusions which were about $500 \mathrm{~nm}$ in diameter, circular in outline, and often clustered around the R body (Fig. 2). The number of endosymbionts having $R$ bodies and virus-like inclusions varied between onequarter and one-half of the total number of symbionts in any one cell. The two types of symbionts could be distinguished in the light microscope (Fig. 3). The total number of symbionts per cell varied widely under different growth conditions, several thousand being usual in starved cells. In any one mass culture, the proportion of symbionts with $\mathrm{R}$ bodies was fairly consistent, differences between cultures usually being more striking than differences within cultures.

Table $\mathrm{I}$ illustrates the association of $\mathrm{R}$ bodies and virus-like inclusions in large forms of the symbiont. Random thin sections were taken and if, in a section, part of an $\mathrm{R}$ body was visible, then virus-like inclusions were always present in the section - the smallest number observed being 6 , and the largest 68 , with a mean of 24.7 . This was the number of virus-like inclusions in a section, not a whole symbiont; serial sections of several large forms showed that about 100 inclusions might be present in a single large symbiont. 


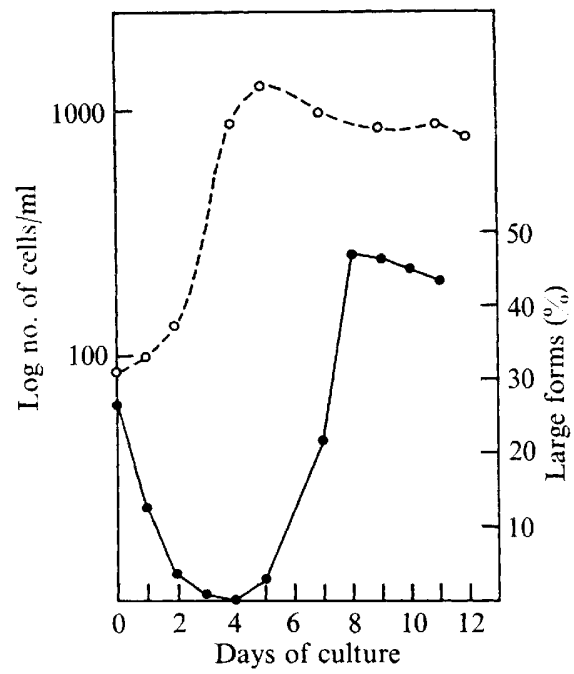

Fig. 4. Decline and rise of the number of large symbionts in cells of stock A35 (- $)$, compared to the growth curve of the culture $\left(\mathrm{O}_{--} \mathrm{O}\right)$.

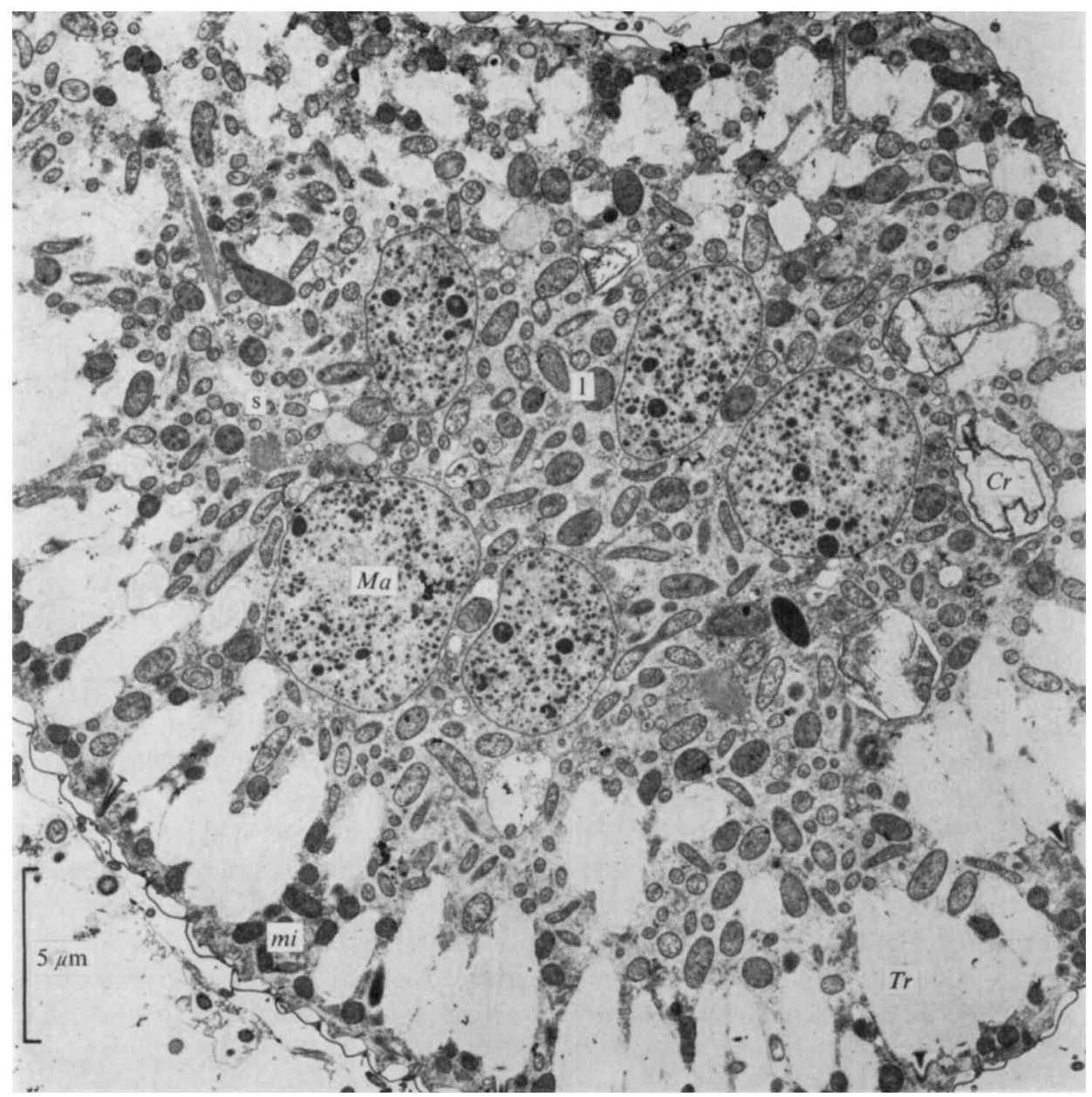

Fig. 5. Low power view of starved cell of stock A35, showing large (1) and small (s) forms of the symbiont. $M a$, Macronucleus; $T r$, trichocyst; $m i$, mitochondria; $C r$, cytoplasmic crystal. 


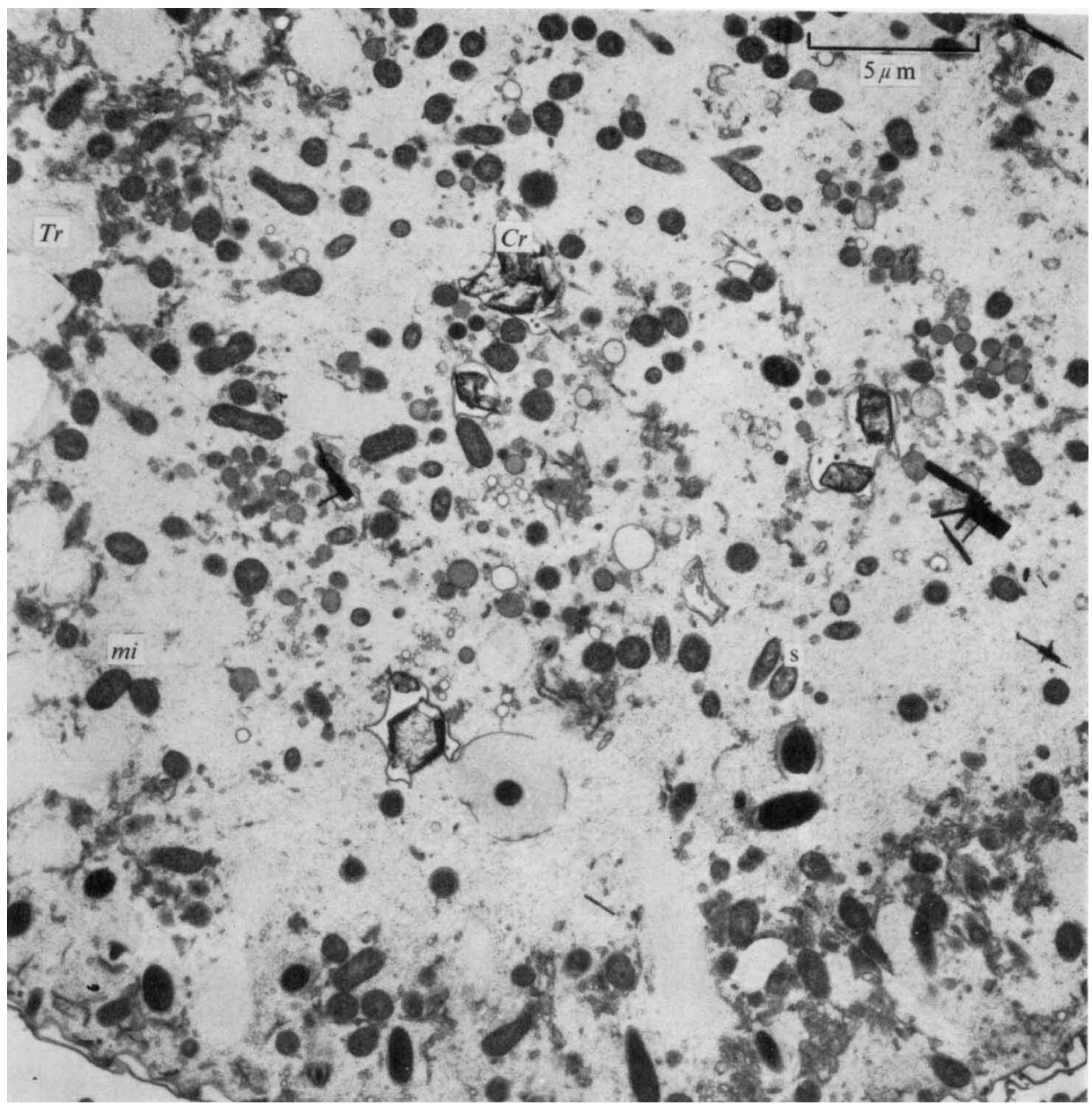

Fig. 6. Low-power view of cell of stock A35 after 3 days of logarithmic growth. Small (s) forms only are evident in much reduced numbers. Other labelling as for Fig. 5.

In most small forms, no virus-like inclusions were visible, but in about $20 \%$ of this class of symbionts, small numbers of virus-like inclusions were found. The highest number observed was I I ; usually there were fewer (Table I), the mean number being 0.74 inclusions per section. It is possible that some of the symbionts scored as small forms were in fact large forms not sectioned through the $\mathrm{R}$ body, thus biasing the result. Alternatively, virus-like inclusions might occasionally occur in small forms.

\section{The relationship between Paramecium growth and symbiont type}

When starved cells, having both large and small kappa forms, were inoculated into fresh culture medium, the number of large symbionts visible in the cells fell rapidly until very few or none could be detected (Fig. 4 to 6). The total number of symbionts in a cell fell also, often by tenfold or more. Disappearance of the large forms was almost complete for a short period.

The mechanism of such a disappearance was not entirely clear. In exponential-phase cells, large forms were occasionally found in vesicles (Fig. 7), suggesting digestion. Symbiont lysis 


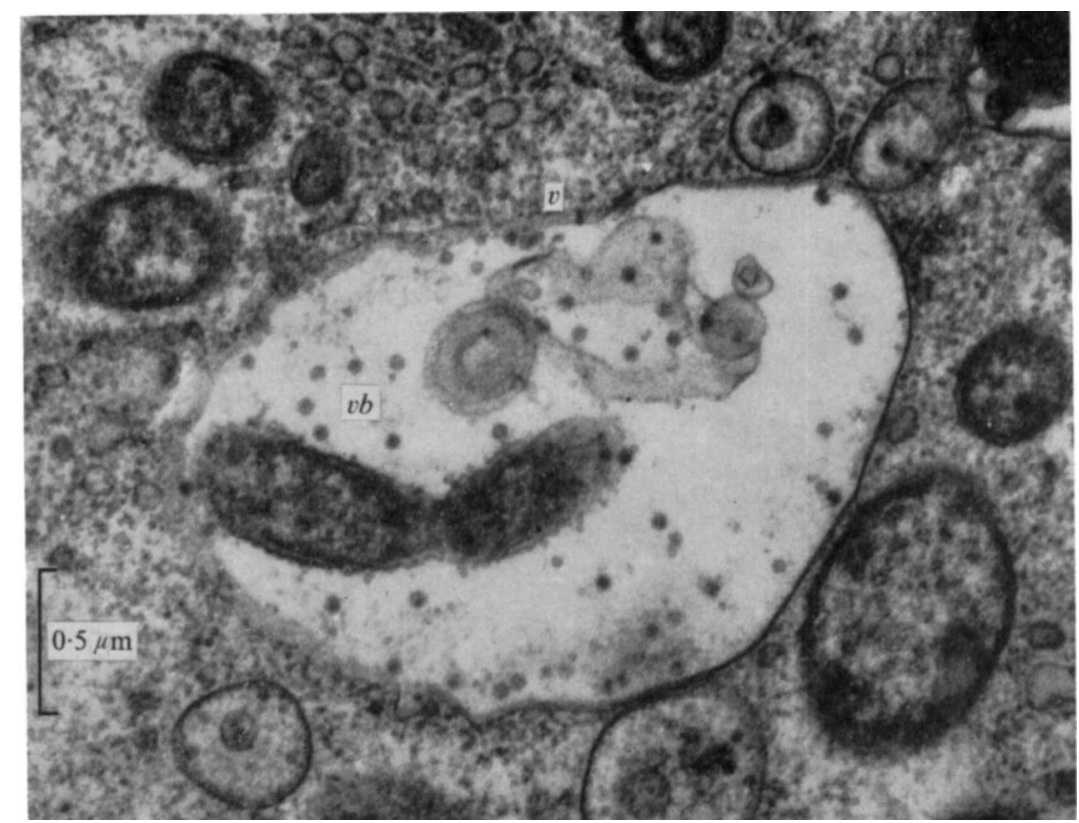

Fig. 7. Large form of stock A35 kappa in a vesicle $(v)$ in the cytoplasm of a logarithmic phase cell. What is possibly the remains of an $\mathrm{R}$ body lies beside the symbiont, with virus-like inclusions scattered around the vesicle. Other symbionts are evident in the surrounding cytoplasm.

Table 2. Effect of maintenance of A35 cells in logarithmic phase on type of symbiont found

Cells were selected after $6,12,15$ and 23 generations and starved. Small forms have no R bodies or bacteriophage-like inclusions; large forms possess these. All starved cells showed both large and small forms after 3 to 4 days of starvation, and the ratios observed were in the region of $25 \%$ arge forms.

$\begin{array}{cccc}\begin{array}{c}\text { No. of } \\ \text { generations }\end{array} & \begin{array}{c}\text { Symbiont } \\ \text { types found }\end{array} & \begin{array}{c}\text { No. of each type } \\ \text { (S, L) }\end{array} & \begin{array}{c}\text { Large } \\ (\%)\end{array} \\ \text { o } & \text { S, L } & 289, \text { I } 87 & 39 \cdot 6 \\ \text { I } & \text { S, L } & 223,64 & 22 \cdot 3 \\ 2 & \text { S, L } & 464,3 \text { I } & 6 \cdot 25 \\ 4 & \text { S, L } & 184,8 & 4 \cdot 2 \\ 6 & \text { S, L } & 167,5 & 2 \cdot 9 \\ \text { I0 } & \text { S, L } & 350, \text { I } & 0 \cdot 3 \\ \text { I3 } & \text { S only } & \text { not counted } & 0 \\ \text { I5 } & \text { S, L } & 320,3 & 0 \cdot 9 \\ 23 & \text { S only } & 237 & 0\end{array}$

might also take place directly in the cytoplasm, but neither this nor virus-like bodies free in the cytoplasm have been seen.

As the culture approached stationary phase, the large forms reappeared. Their appearance coincided with the slowing down from exponential growth. With prolonged maintenance of stationary phase (starvation) the proportion of large forms built up to one-quarter to onehalf of the total number of symbionts.

After a period of starvation, cells sometimes underwent autogamy (internal self-fertilization). Usually, there was then a reduction of the number of symbionts in the cell (to 
one-third or one-quarter of the original total) but both forms persisted. Inoculation of autogamous cells into fresh medium caused the disappearance of large forms. If cells were kept in exponential growth by repeated separation of sister cells into fresh medium at division, then small forms only of the symbionts were observed (Table 2). In such an experiment, logarithmic growth was maintained for 23 generations. Large symbiont forms appeared in cells subjected to starvation at any time. After 4 days of starvation, the proportion of large forms was $25 \%$ or more, regardless of when the cells were withdrawn from exponential growth.

\section{DISCUSSION}

The distinctive characteristic of kappa symbionts is the possession of refractile $(R)$ bodies by a proportion of the symbionts. Killing is associated with the forms bearing $\mathrm{R}$ bodies (Smith, I96I; Mueller, I963; Preer \& Preer, 1964). In kappa of stock A35, symbionts with $\mathrm{R}$ bodies have been named 'large' because of their marked increase in size compared to symbionts without $\mathrm{R}$ bodies. $\mathrm{R}$ bodies are hollow membranous structures (Dippell, 1958; Rudenberg, 1962) that can 'unroll' in response to various stimuli (Mueller, 1962; Anderson, Preer, Preer \& Bray, 1964; Preer, Hufnagel \& Preer, 1966); unrolling may be associated with delivery of a toxin to its site of action, which may be the apparatus forming the food vacuole (Jurand, Rudman \& Preer, 1971). Virus-like inclusions are associated with the R body in some kappa types (Preer \& Preer, 1967; Preer \& Jurand, I968; Stevenson, 1970).

All kappa-bearing stocks of Paramecium aurelia appear to belong to syngens 2 and 4 , and there are differences in the kappa symbionts found in each syngen (Beale et al. 1968). The symbiont described in this paper conforms to a syngen 2 type. It is not known if specific Paramecium nuclear genes are necessary for its maintenance.

The kappa symbiont of stock A35 has an ultrastructure similar to other described types. The virus-like inclusions are smaller in size and more numerous than those described by Preer \& Jurand (1968). As in the earlier instance, however, there is a strong association with the $\mathrm{R}$ body. It seems reasonable to suppose that the virus-like inclusions may be a bacteriophage of the kappa symbiont. Preer, Preer, Rudman \& Jurand (I97I) isolated the virus-like inclusions from another type of kappa symbiont and found that their composition is comparable to that of a bacteriophage. The small forms of kappa could thus be considered lysogenic, carrying prophage, while in the large forms induction has taken place. Whether or not the phage can cause lysis of its bacterial endosymbiont host is presently unknown; the fate of free bacteriophage in the Paramecium cytoplasm would be difficult to ascertain.

It has been established that in other kappa types the symbionts containing $\mathrm{R}$ bodies develop from those without $\mathrm{R}$ bodies, and having developed $\mathrm{R}$ bodies they lose the ability to divide (Smith, I96I; Mueller, 1963). A similar situation seems to hold in A35 kappa, as large symbionts are never observed in the course of division, but small ones often are. The small-to-large change in $\mathrm{A} 35$ kappa requires both virus-like inclusions and $\mathrm{R}$ body production. The $\mathrm{R}$ body might be a phage product, specified by phage genes, and necessary for maturation and infection. Preer \& Preer (1967) considered that the $R$ body was important in delivering a kappa toxin to its site of action in the sensitive cell, and found that virus-like particles might be associated with the unrolled $\mathrm{R}$ body. Possibly the virus-like inclusions might be the toxic agent. If the $\mathrm{R}$ body were a phage product, then $\mathrm{R}$ body production would be an example of phage conversion, and, as such, comparable to $\mathrm{E}$ antigen production in Salmonella typhimurium or toxin production in Corynebacterium diphtheriae (Hayes, 1968).

Symbionts are on occasion observed in vesicles in actively growing cells. A number of endosymbionts of Paramecium aurelia occur in vesicles (Beale et al. 1969; Stevenson, 1970), 
but kappa symbionts normally do not. Vesicles of various types, some of which have digestive function, are common in the cytoplasm of $P$. aurelia (Jurand \& Selman, 1969), so symbionts might be digested in this way. Small forms have not been observed in such vesicles, suggesting that if digestion occurs, the large forms may be preferentially digested. Lysis of large forms has not been observed either in logarithmic or in stationary phase cells. Both lysis and subsequent digestion may be rapid processes, thus accounting for their non-observation.

There is thus in stock A35 of Paramecium aurelia a symbiotic relationship of some complexity and the conditions the ciliate host finds itself in influence the conditions of internal symbionts.

I should like to thank Professor D. J. Carr and Dr G. D. Clark-Walker for their comments, and Mrs A. Gallagher for technical assistance.

\section{REFERENCES}

Anderson, J. F., Preer, J. R., Preer, L. B. \& Bray, M. (1964). Studies on killer particles from Paramecium; structure of refractile bodies of $\mathrm{K}$ particles. Journal de Microscopie 3, 395-402.

Beale, G. H. \& Jurand, A. (1966). Three different types of mate-killer $(\mu)$ particles in Paramecium aurelia syngen I. Journal of Cell Science I, 3I-34.

Beale, G. H., Jurand, A. \& Preer, J. R. (1969). The classes of endosymbiont in Paramecium aurelia. Journal of Cell Science 5, 65-9r.

Dippelx, R. V. (1958). The fine structure of kappa in killer stock 5I of Paramecium aurelia. Preliminary observations. Journal of Biophysical and Biochemical Cytology 4, I25-I28.

HAYES, W. (1968). The Genetics of Bacteria and their Viruses, 2nd ed, pp. I-925. Oxford: Blackwell.

Jurand, A., Rudman, B. M. \& Preer, J. R. (1971). Prelethal effects of killing action by stock 7 of Paramecium aurelia. Journal of Experimental Zoology 177, 365-388.

Jurand, A. \& Selman, G. G. (1969). The Anatomy of Paramecium aurelia, pp. I-2 18. London: Macmillan.

MUELLER, J. A. (1962). Induced physiological and morphological changes in the B particles and R body from killer paramecia. Journal of Protozoology 9, Supplement 26.

MuELLER, J. A. (1963). Separation of kappa particles with infective activity from those with killing activity and identification of the infective particles in Paramecium aurelia. Experimental Cell Research 30, 492-508.

Preer, J. R., Hufnagel, L. A. \& Preer, L. B. (1966). Structure and behaviour of R bodies from killer paramecia. Journal of Ultrastructure Research 15, 13I-143.

Preer, J. R. \& Jurand, A. (1968). The relation between virus-like particles and R bodies of Paramecium aurelia. Genetical Research 12, 33I-40.

Preer, J. R. \& Preer, L. B. (1967). Virus-like bodies in killer paramecia. Proceedings of the National Academy of Science of the United States of America 58, 1774-178I.

Preer, J. R., Preer, L. B., Rudman, B. \& Jurand, A. (197I). Isolation and composition of bacterophagelike particles from kappa of killer Paramecium. Molecular \& General Genetics xII, 202-208.

Preer, L. B. \& Preer, J. R. (1964). Killing activity from lysed particles of Paramecium. Genetical Research 5, 230-239.

RudenberG, F. H. (1962). Electron-microscopic observations of kappa in Paramecium aurelia. Texas Reports of Biology and Medicine 20, I05-I I 2.

SмrтH, J. E. (196I). Purification of kappa particles of stock 5I of Paramecium aurelia. American Zoologist $\mathbf{\mathbf { }}$, 390.

SONNEBORN, T. M. (1943). Gene and cytoplasm. I. The determination and inheritance of the killer character in variety 4 of Paramecium aurelia. Proceedings of the National Academy of Science of the United States of America 29, 329-343.

SONNEBORn, T. M. (1950). Methods in the general biology and genetics of Paramecium aurelia. Journal of Experimental Zoology Ir3, 87-143.

STEVEnSON, I. (1970). Endosymbiosis in some stocks of Paramecium aurelia collected in Australia. Cytobios 2, 207-224. 